\title{
PROFIL STRATEGI PEMBELAJARAN BAHASA JEPANG DI KELAS 3 SD SARASWATI 3 DENPASAR
}

\author{
Astari, K. A. $Y^{1}$, Mardani, D. M. $\mathrm{S}^{2}$, dan Hermawan, G. $\mathrm{S}^{3}$ \\ 123 Jurusan Pendidikan Bahasa Jepang, Universitas Pendidikan Ganesha, Singaraja,Bali \\ e-mail:ykadek35@gmail.com, desak.mardani@undiksha.ac.id, satya.hermawan@undiksha.ac.id
}

\begin{abstract}
Abstrak
Penelitian ini bertujuan untuk menganilis (1) sasaran pembelajaran bahasa Jepang di kelas 3, (2) strategi pembelajaran yang digunakan untuk mencapai sasaran pembelajaran bahasa Jepang di kelas 3, (3) faktor-faktor yang mendasari penggunaan strategi dalam pembelajaran bahasa Jepang di kelas 3, dan (4) kendala-kendala yang dihadapi dalam pembelajaran bahasa Jepang di kelas 3 SD Saraswati 3 Denpasar. Penelitian ini merupakan penelitian deskriptif kualitatif. Subjek penelitian ini yaitu guru yang mengajar bahasa Jepang di kelas 3 SD Saraswati 3 Denpasar. Metode pengumpulan data yang digunakan yaitu observasi, wawancara, dan dokumentasi. Hasil penelitian ini menunjukkan bahwa (1) sasaran pembelajaran bahasa Jepang di kelas 3 adalah siswa mampu mengembangkan keterampilan dalam berbahasa Jepang meliputi empat aspek yaitu aspek menyimak, aspek berbicara, aspek membaca, dan aspek menulis. (2) Strategi pembelajaran yang digunakan untuk mencapai sasaran pembelajaran bahasa Jepang di kelas 3 yaitu strategi drill dan strategi tanya jawab. (3) Faktor-faktor yang mendasari penggunaan strategi dalam pembelajaran bahasa Jepang di kelas 3 yaitu karakteristik siswa, dan kondisi siswa di kelas. (4) Kendala-kendala yang dihadapi dalam kegiatan pembelajaran bahasa Jepang di kelas 3 adalah penggunaan media pembelajaran, dan kendala alokasi waktu
\end{abstract}

Kata kunci: bahasa Jepang, profil, strategi pembelajaran

\section{要旨}

本研究の目的は、デンパサルサラスワティ第三私立小学校三年生において、（1）日本 語学習の目標、（2）日本語学習の目標を達成するための学習ストラテジー、（3）日本語 学習におけるストラテジー使用の要因、（4） 日本語学習の障害を記述することである。研 究の対象は、デンパサルサラスワティ第三私立小学校三年生の日本語教師である。観察、イ ンタビュー及び、文献調査によって収集したデータを定性的記述法により分析した。その結 果、（1） 日本語学習の目標は、聴く力・読む力・話寸力・書く力という 4 技能において、 日本語能力を伸ばすことが出来ることである。（2）日本語学習の目標を達成するための学 習ストラテジーは、ドリルストラテジーとQ\&Aストラテジーである。（3）日本語学習にお けるストラテジー使用の要因は、生徒の特性、教室にての生徒の状態である。（4）日本語 学習の障害は、教材の利用と時間割である。

キーワード：日本語、概要、学習ストラテジー

\section{Pendahuluan}

Strategi pembelajaran merupakan aspek yang sangat penting dalam berlangsungnya proses belajar mengajar di kelas. Strategi pembelajaran juga merupakan aspek yang sangat penting dalam berlangsungnya proses belajar mengajar di kelas. Sementara itu, dari hasil observasi awal di beberapa SD di Denpasar yang mulai memperoleh pelajaran bahasa Jepang, siswa SD masih diajarkan dengan cara atau strategi yang tidak jauh berbeda 
dengan strategi mengajar siswa SMP dan SMA. Pembelajaran terpaku pada buku teks, lalu memberikan latihan tanya jawab maupun drill. Strategi pembelajaran yang digunakan sama walaupun jenis dan tahapan yang dicapai berbeda melihat karakteristik perkembangan anak pada setiap tingkatan sekolah terutama di SD berbeda dikarenakan adanya kelas rendah dan kelas tinggi. Berdasarkan observasi awal yang dilakukan di sekolah-sekolah dasar di Denpasar yang telah memperoleh pembelajaran bahasa Jepang, SD Saraswati 3 Denpasar yang berlokasi di Denpasar mengambil kebijakan bahwa pembelajaran bahasa Jepang yang diberikan kepada seluruh siswa berupa muatan lokal serta ekstrakurikuler dengan tujuan yaitu menjadi daya tarik lebih bagi sekolah.

Ketika mengajar masing-masing guru bahasa Jepang di SD Saraswati 3 Denpasar menggunakan strategi dan metode pembelajaran yang tidak jauh berbeda antara kelas 1 hingga kelas 6 , namun dalam penerapan yang sedikit berbeda. Hal ini disesuaikan dengan karakteristik siswa dan tahap perkembangan berpikir siswa sekolah dasar. Hal ini menarik karena guru dituntut mampu untuk memilih strategi dan metode pembelajaran yang tepat yang digunakan untuk pembelajaran bahasa Jepang di SD.

Berdasarkan observasi dan wawancara yang peneliti lakukan di SD Saraswati 3 Denpasar, peneliti memilih untuk meneliti proses pembelajaran di kelas 3 karena masih tergolong tingkatan kelas rendah dan dari proses pembelajaran bahasa Jepang yang diamati di kelas 3 berlangsung cukup kondusif, siswa cukup siap untuk menerima pelajaran di kelas. Hal ini dibuktikan dengan antusiasnya siswa untuk mengikuti pembelajaran dan mendengarkan penjelasan dari guru. Sedangkan proses pembelajaran di kelas 1 dan 2 berlangsung tidak kondusif, terbukti ketika guru menjelaskan namun semua siswa juga ikut berbicara dan bermain. Materi pembelajaran di kelas 3 tidak hanya sebatas kosa kata tetapi sudah pada penggunaan kalimat sederhana. Kemudian di kelas 3 pula lebih ditekankan pada pemahaman huruf hiragana dan katakana, maka guru menggunakan metode tanya jawab, dan drill.

Penelitian mengenai pembelajaran bahasa Jepang sebelumnya pernah dilakukan oleh Yogisswara (2015) penelitian yang dilakukan merupakan penelitian deskriptif kualitatif dengan berfokus dengan berfokus pada pembelajaran bahasa Jepang di tingkat SMA. Tujuan penelitian ini adalah untuk mendeskripsikan sasaran pembelajaran bahasa Jepang di kelas 3 SD Saraswati 3 Denpasar, untuk mendeskripsikan strategi pembelajaran yang digunakan untuk mencapai sasaran pembelajaran bahasa Jepang di kelas 3 SD Saraswati 3 Denpasar, untuk mendeskripsikan faktor-faktor yang mendasari penggunaan strategi dalam pembelajaran bahasa Jepang di kelas SD Saraswati 3 Denpasar, dan untuk mendeskripsikan kendala-kendala yang dihadapi dalam kegiatan pembelajaran bahasa Jepang di kelas 3 SD Saraswati 3 Denpasar.

Pembelajaran bahasa Jepang di Indonesia umumnya diajarkan sebagai bahasa asing. Susanto (2013) menyatakan kata pembelajaran adalah gabungan dari dua aktivitas yaitu belajar dan mengajar. Istilah pembelajaran adalah penyederhanaan dari kata belajar dan mengajar, proses belajar dan mengajar, ataupun kegiatan belajar mengajar. Bahasa asing dalam pendidikan memiliki arti belajar berkomunikasi menggunakan bahasa yang memang belum pernah diketahui dan dipelajari sebelumnya oleh peserta didik kemudian didapatkan melalui proses belajar atau pendidikan formal sehingga dalam pembelajaran bahasa asing memperoleh tujuan belajar yang sesuai, tujuannya yaitu dapat digunakan sebagai alat untuk berkomunikasi.

Proses belajar mengajar akan terbentuk sesuai dengan pemahaman pendidik mengenai karakteristik peserta didik serta hakikat pembelajaran itu sendiri. Oleh karena itu, pendidik perlu memahami dengan baik tentang karakteristik peserta didik khususnya di tingkat sekolah dasar kelas rendah (Kawuryan, 2011). Tingkatan kelas pada sekolah dasar terdiri dari enam kelas, yang dibedakan menjadi kelas awal atau kelas rendah untuk kelas 1 , kelas 2, dan kelas 3 serta kelas tinggi yang terdiri dari kelas 4 sampai dengan kelas 6 . Rentang usia peserta didik sekolah dasar yaitu $6-12$ tahun. Peserta didik pada tingkat kelas rendah mempunyai rentang usia 6 atau 7 sampai 8 atau 9 tahun.

Pertumbuhan fisik juga sebagai salah satu karakteristik perkembangan peserta didik kelas rendah yang biasanya sudah mencapai kematangan. Sedangkan untuk perkembangan 
kecerdasan peserta didik pada kelas rendah terlihat dengan kemampuannya yang telah dapat mengelompokkan objek, berminat terhadap angka dan tulisan, senang berbicara, meningkatnya perbendaharaan kosa kata serta memahami sebab akibat dan mulai berkembangnya pemahaman mengenai ruang dan waktu (Kawuryan, 2011).

Strategi pembelajaran merupakan cara-cara yang digunakan oleh pendidik untuk mengajar sehingga peserta didik akan mudah untuk menerima dan memahami materi pembelajaran yang diberikan dan tujuan pembelajaran akan tercapai. Padmadewi (2012) mengungkapkan bahwa ada beberapa strategi lain untuk pembelajaran bahasa asing diantaranya sebagai berikut.

Latihan atau drill ini merupakan suatu cara mengajar dimana guru memberikan latihanlatihan kepada siswa guna melatih keterampilan dan ketangkasan yang lebih tinggi dari apa yang telah dipelajari sebelumnya (Roestiyah, 2001).

Roestiyah (2001) menyatakan bahwa tanya jawab merupakan suatu teknik atau strategi mengajar dengan tujuan untuk memberikan motivasi kepada siswa agar lebih aktif untuk bertanya. Tujuan digunakannya strategi ini adalah untuk mengetahui penguasaan siswa terhadap materi pelajaran dan mendorong siswa berani mengajukan pertanyaan kepada guru tentang masalah yang belum dipahami.

Kendala dalam pembelajaran adalah beberapa masalah yang menghambat jalannya proses pembelajaran yang dilihat dari faktor manusiawi yakni guru dan peserta didik, faktor intitusional yaitu ruang kelas, dan intruksional yaitu kurangnya alat peraga (Hamalik, 2002:16).

Guru pasti memiliki kendala atau hambatan yang dihadapi selama proses kegiatan pembelajaran. Sama seperti guru bahasa Jepang di SD Saraswati 3 Denpasar yang juga menghadapi kendala-kendala dalam kegiatan pembelajaran.

\section{Metode}

Pada metode penelitian terdapat enam langkah yang dilakukan diantaranya, pendekatan dan jenis penelitian, lokasi penelitian, sumber data, metode pengumpulan data, metode dan teknis analisis data, serta pengecekan kebasahan data.

Penelitian ini dilakukan di salah satu sekolah dasar yaitu SD Saraswati 3 Denpasar yang berlokasi di Jalan Mohammad Yamin IV No.1, Denpasar Selatan.

Subjek dalam penelitian ini adalah guru yang mengajar bahasa Jepang di kelas 3 SD Saraswati 3 Denpasar. Objek dalam penelitian ini adalah (1) sasaran pembelajaran bahasa Jepang yang ada di kelas 3 SD Saraswati 3 Denpasar, (2) strategi yang digunakan dalam pembelajaran bahasa Jepang di kelas 3 SD Saraswati 3 Denpasar, (3) faktor-faktor yang mendasari penggunaan strategi dalam pembelajaran bahasa Jepang di kelas 3 SD Saraswati 3 Denpasar, (4) kendala-kendala yang dihadapi dalam kegiatan pembelajaran bahasa Jepang di kelas 3 SD Saraswati 3 Denpasar.

Kualitas pengumpulan data merupakan salah satu faktor utama yang memengaruhi kualitas data hasil penelitian selain kualitas instrumen (Sugiyono 2007:193). Pada penelitian ini digunakan tiga metode pengumpulan data untuk mengumpulkan data yang tepat, tiga metode tersebut yaitu metode observasi, observasi yang dilakukan adalah observasi nonpartisipan yang dilaksanakan sebanyak empat kali pada rabu (10 Januari 2018), kamis (18 Januari 2018), sabtu (3 Februari 2018), dan rabu (14 Februari 2018), metode wawancara yang digunakan adalah wawancara terstruktur yang dilaksanakan setelah observasi, dan metode dokumentasi dilaksanakan selama proses pembelajaran bahasa Jepang di kelas 3 berlangsung.

Arikunto (2005:269) menyatakan metode analisis data dengan menggunakan metode deskriptif kualitatif dilakukan sesuai dengan keadaan sebenarnya. Teknik analisis data yang digunakan dalam penelitian ini dibagi menjadi lima langkah diantaranya yang pertama ada tabulasi data merupakan tahap menggabungkan semua data yang diperoleh dari hasil observasi, wawancara, dan dokumentasi kemudian akan diklasifikasikan berdasarkan profil pembelajaran bahasa Jepang, sasaran pembelajaran, strategi pembelajaran, faktor-faktor 
yang mendasari penggunaan strategi tersebut, dan kendala yang dihadapi guru dalam pembelajaran.

Langkah kedua yaitu reduksi data yang merupakan proses pemilihan, penyederhanaan, peringkasan data mentah data mentah yang diperoleh dari hasil observasi pembelajaran bahasa Jepang di kelas 3, hasil wawancara dengan guru bahasa Jepang dan hasil dokumentasi di kelas 3 SD Saraswati 3 Denpasar.

Ketiga yaitu deskripsi data yang merupakan tahap seluruh data yang diperoleh melalu observasi dan wawancara dideskripsikan dengan fakta yang ditemukan di lapangan. Keempat yaitu klasifikasi data merupakan tahap mengklasifikasikan dan mengelompokkan hasil observasi dan wawancara secara garis besar yaitu, sasaran pembelajaran bahasa Jepang yang ada di kelas 3 SD Saraswati 3 Denpasar, strategi yang digunakan dalam pembelajaran bahasa Jepang di kelas 3 SD Saraswati 3 Denpasar, faktor-faktor yang mendasari penggunaan strategi dalam pembelajaran bahasa Jepang di kelas 3 SD Saraswati 3 Denpasar, kendala-kendala yang dihadapi dalam kegiatan pembelajaran bahasa Jepang di kelas 3 SD Saraswati 3 Denpasar.

Langkah kelima ada penarikan kesimpulan yaitu disesuaikan dengan data yang valid yang ditemukan di lapangan, kemudian barulah dapat menarik kesimpulan yang merupakan jawaban atas permasalahan dari penelitian ini.

\section{Hasil dan Pembahasan}

Dalam Penelitian ini observasi dilakukan dalam pembelajaran bahasa Jepang yang terdapat di kelas 3 SD Saraswati 3 Denpasar. Observasi dilakukan sebanyak empat kali, dengan guru yang mengajar bahasa Jepang di kelas 3 sebagai subjek penelitian. Hal-hal yang diamati pada proses observasi yaitu, strategi pembelajaran yang digunakan guru, media yang digunakan, dan kendala-kendala yang dihadapi pada pembelajaran bahasa Jepang.

Data yang diperoleh pada observasi pertama yaitu, guru mengajarkan materi "Katakana 1". Guru selama proses pembelajaran menggunakan strategi drill dan tanya jawab. Pada penerapan strategi drill dan tanya jawab guru memberikan kesempatan dan waktu lebih kepada siswa untuk menjawab dikarenakan karakter dan cara berpikir siswa di kelas rendah masih tergolong abstrak. Latihan drill dilakukan yang pertama oleh guru dan seluruh siswa, kedua oleh guru dan kelompok siswa, dan ketiga oleh guru dan siswa per individu. Guru dalam penerapan strategi lebih sering tanpa menggunakan media gambar namun benda-benda di kelas.

Data yang diperoleh pada observasi kedua yaitu, guru mengajarkan materi "Ikura Desuka". Guru mengajarkan materi tersebut menggunakan strategi drill dan tanya jawab. Guru memberikan strategi drill lebih sering di awal pembelajaran dan inti pembelajaran. Media yang digunakan yaitu berupa jari tangan karena menyesuaikan dengan materi tentang bilangan dan angka. Strategi tanya jawab yang dilakukan guru tidak dilakukan dengan maksimal dikarenakan alokasi waktu yang sedikit.

Data yang diperoleh pada observasi ketiga yaitu, guru mengajarkan materi "Katakana 2". Guru mengajarkan materi tersebut dengan menggunakan strategi drill dan tanya jawab. Guru melakukan fukushuu mengenai materi huruf katakana sebelumnya. Pada latihan menulis huruf, guru menggunakan teknik menulis di udara lalu siswa mengikutinya. Guru tidak menggunakan media gambar untuk drill dan tanya jawab melainkan guru hanya menyebutkan kosa kata dengan bahasa ibu, lalu siswa menjawab dengan bahasa Jepang.

Data yang diperoleh pada observasi keempat yaitu, guru mengajarkan materi "Heya No Shinamono". Guru mengajarkan materi dengan strategi drill dan tanya jawab, dan lebih banyak menggunakan bahasa Indonesia. Media pembelajaran yang digunakan adalah media kartu gambar. Guru lebih menekankan strategi drill menebak dengan tepat tetapi memberikan waktu lebih dan kesempatan untuk menjawab dikarenakan cara berpikir siswa pada kelas rendah masih tergolong abstrak.

\section{Data Hasil Wawancara}

Berdasarkan hasil wawancara, guru bahasa Jepang di kelas 3 SD Saraswati 3 Denpasar sudah mengajar bahasa Jepang di SD Saraswati 3 Denpasar selama kurang lebih 8 tahun, sedangkan untuk pembelajaran bahasa Jepang sebagai muatan lokal sudah 
diberikan sejak tahun 2005. Ciri khas pembelajaran bahasa Jepang di SD Saraswati 3 Denpasar adalah setiap tahunnya ada kunjungan tetap mahasiswa Jepang sebanyak dua sampai tiga kali ke sekolah dan hal tersebut menarik minat siswa untuk belajar bahasa Jepang. Dalam proses pembelajarannya, agar tetap berjalan efektif guru dan siswa menggunakan bahan ajar berupa buku penunjang yaitu Nihongo No Kyoukashou yang merupakan buku khusus untuk Sekolah Dasar dan bersifat intern. Dalam usaha mencapai sasaran pembelajaran tersebut, guru menggunakan bahan ajar yang sifatnya intern dan dibuat khusus untuk siswa Sekolah Dasar, metode pembelajaran yang digunakan oleh guru adalah GTM (Grammar Translation Method), strategi pembelajaran yang digunakan adalah strategi drill dan tanya jawab menyesuaikan dengan karakteristik siswa SD di kelas 3 yang mulai siap untuk belajar dan senang berbicara.

Pada proses pembelajaran dalam penyajian materi guru menggunakan tahapan proses pembelajaran bahasa Jepang dasar. Tahap pertama yang dilakukan guru yaitu menggunakan 導入(Dounyuu/latihan pengenalan) dengan menggunakan bahasa ibu (bahasa Indonesia). Dalam pengajarannya ada beberapa langkah yang dilakukan oleh guru yaitu, melakukan fukushuu atau mengulang materi yang diajarkan sebelumnya untuk mengukur sejauh mana pemahaman siswa mengenai materi yang telah diajarkan sebelumnya. Kemudian menjelaskan tujuan pembelajaran, lalu melanjutkan ke materi baru yang akan diajarkan pada saat itu.

Tahap kedua, proses dilanjutkan dengan 基本練習 (Kihon renshuul latihan dasar) yang dilatihkan yaitu latihan pengulangan (反復練習), latihan tanya menjawab dan merespon

(応答練習) yang terjadi antara guru dengan siswa. Dalam pelaksanaan latihan antara guru dengan siswa, guru akan terlebih dahulu memperkenalkan kosa kata, setelah siswa memahami kosa kata yang telah diberikan tersebut kemudian guru akan menjelaskan pola kalimat yang masih tergolong sangat sederhana yang sesuai dengan pemahaman anak sekolah dasar.

Guru memperkenalkan kosa kata-kosa kata baru yang sudah ada di dalam buku penunjang. Kemudian memberikan siswa latihan hatsuon (pengucapan dalam bahasa Jepang) dari masing-masing kosa kata agar siswa mengetahui dan mampu mengucapkan setiap kosa kata dengan baik dan benar karena hatsuon merupakan salah satu hal yang penting dalam pembelajaran bahasa Jepang, jika hatsuonnya salah maka makna yang muncul akan berbeda. Dalam latihan kosa kata di dalam kelas guru melakukan dengan strategi drill sebagai latihan dasar. Latihan drill dilakukan oleh seluruh siswa, latihan drill yang pertama dilakukan oleh guru dan semua siswa,latihan drill yang kedua dilakukan oleh guru dan kelompok siswa. Kemudian tahap yang ketiga yakni 応用練習 (Ouyou renshuu/Latihan penggunaan) dalam hal ini guru menggunakan latihan tanya jawab antara guru dengan siswa.

Strategi pembelajaran yang digunakan oleh guru bahasa Jepang di kelas 3 SD Saraswati 3 Denpasar adalah strategi drill dan tanya jawab. Strategi pembelajaran ini diikuti siswa dengan sangat baik dan siswa terlihat aktif mengikuti pelajaran terbukti dengan sikap siswa yang sungguh-sungguh dan antusias pada saat guru menjelaskan materi. Faktor yang mendasari pemilihan strategi mengajar guru yaitu karakteristik siswa yang menjadi alasan utama guru menggunakan strategi drill dan tanya jawab dalam proses pembelajaran, karena jika dilihat dari minat siswa apalagi dalam tahap usia dini, minat mereka dalam belajar bahasa Jepang masih kurang dan belum bisa belajar dengan serius dalam waktu yang cukup lama. Siswa juga merasa cepat bosan jika hanya guru yang sibuk menjelaskan materi di depan kelas. Strategi drill dan tanya jawab diterapkan agar tidak hanya guru saja yang berperan dalam pembelajaran melainkan siswa juga harus ikut berperan aktif dalam proses belajar sehingga tercapai tujuan pembelajaran yang diinginkan.

Kendala yang dihadapi guru dalam pembelajaran bahasa Jepang yaitu jumlah siswa yang terlalu banyak maka guru pada saat memberikan latihan terkadang kurang maksimal. Kendala lainnya adalah alokasi waktu pembelajaran yang terbatas serta sarana dan prasarana yang kurang mendukung seperti LCD yang tidak bisa digunakan. 


\section{Pembahasan \\ Sasaran Pembelajaran Bahasa Jepang di Kelas 3 SD Saraswati 3 Denpasar}

Sasaran pembelajaran bahasa Jepang yang ada di kelas 3 SD Saraswati 3 Denpasar secara umum sama dengan sasaran pembelajaran di kelas 1 sampai dengan kelas 6 yaitu agar siswa mampu mengembangkan keterampilan dalam berbahasa Jepang meliputi empat aspek yaitu, aspek menyimak, aspek berbicara, aspek membaca, dan aspek menulis. Pada kelas 3 sasaran pembelajaran mulai lebih kompleks dari kelas sebelumnya yaitu yang pertama pada aspek menyimak siswa mampu membedakan bunyi dan kata yang pengucapannya memiliki kemiripan. Sasaran pertama dapat dicapai dengan melatih pendengaran siswa melalui guru ketika melakukan latihan pengucapan kosa kata secara berulang-ulang kemudian siswa mendengarkan lalu membedakan setiap bunyi dan kata tersebut. Misalnya guru mengucapkan kosa kata bilangan yaitu ni sen, san zen, dan hassen secara berulang lalu guru akan meminta siswa mengucapkannya kembali kemudian bertanya kepada siswa "san zen pakai s atau pakai z?", hal yang sama juga dilakukan pada saat mengucapkan hassen lalu guru akan bertanya "sekarang apa bedanya san zen dengan hassen?". Siswa pun menjawab dengan membedakan huruf yang ada pada "san zen" memakai z sedangkan "hassen" memakai s. Sasaran ini terlihat pada setiap kelas yang diobservasi.

Sasaran yang kedua pada aspek berbicara yaitu siswa mampu melafalkan bunyi, kata, dan mengucapkan salam. Sasaran kedua dapat dicapai dengan latihan pengulangan kosa kata maupun kalimat yang dilakukan dengan tanya jawab oleh guru mengenai materi yang telah diajarkan. Jika terjadi kesalahan dalam melafalkan guru akan mengoreksinya langsung. Hal ini terlihat pada setiap kelas yang diobservasi.

Sasaran yang ketiga pada aspek membaca yaitu siswa mampu membaca tulisan dalam huruf katakana. Sasaran yang ketiga dapat dicapai dengan latihan membaca yang dilakukan oleh siswa. Siswa secara bergantian membaca tulisan dalam huruf katakana yang sudah ada dalam buku penunjang, namun praktik membaca ini tidak memberikan kesempatan kepada seluruh siswa melainkan hanya beberapa siswa saja. Setelah membaca, guru juga membantu siswa untuk menerjemahkan kosa kata berupa gambar yang ada di buku, sehingga siswa tidak hanya bisa membaca huruf katakana saja, namun juga paham mengenai arti dari kosa kata tersebut.

Sasaran pembelajaran yang keempat pada aspek menulis yaitu siswa mampu untuk menulis kata menggunakan huruf katakana. Sasaran keempat bisa dicapai dengan melatih siswa dalam menulis katakana, karena huruf hiragana sudah ditekankan pada semester lalu namun penulisan menggunakan huruf hiragana juga tetap dilatih agar siswa tidak mudah lupa. Siswa diajarkan berlatih urutan goresan penulisan dari setiap huruf katakana tersebut dengan berlatih menulis di udara secara bersamaan sambil mengucapkan banyaknya goresan penulisan, lalu dilanjutkan dengan latihan menulis huruf katakana di buku kotak ataupun buku penunjang siswa. Pada aspek menulis siswa di kelas 3 hanya diharapkan mampu menulis kosa kata dan kalimat pendek yang masih tergolong sederhana menggunakan huruf hiragana dan katakana belum sampai pada latihan menulis dan mengarang pada genkouyoushi seperti yang dilakukan siswa tingkat SMA karena materi yang diberikan tergolong sangat sederhana.

\section{Strategi Pembelajaran yang Digunakan dalam Mengajar}

Strategi yang diterapkan guru dalam proses belajar mengajar di keempat kelas tersebut adalah strategi drill dan tanya jawab. Penggunaan strategi drill ini sudah terlihat diterapkan oleh guru dari observasi pertama sampai dengan observasi keempat. Drill lebih sering digunakan pada saat melakukan latihan mengenai huruf katakana dan kosa kata-kosa kata baru. Strategi drill ini cocok dilakukan dalam proses belajar mengajar di kelas 3 karena dapat membuat siswa lebih aktif dan melatih keterampilan berbicara. Hal ini sejalan dengan pendapat Kawuryan (2011) yang menyatakan bahwa perkembangan kecerdasan peserta didik pada kelas rendah terlihat dengan kemampuannya yang senang berbicara, berminat dengan angka dan tulisan, serta meningkatnya perbendaharaan kosa kata peserta didik. Jenis drill yang digunakan oleh guru di kelas 3 yaitu repetition drill (latihan pengulangan), 
karena jenis drill ini merupakan drill paling mudah dan tidak mengubah kalimat sesuai dengan materi pelajaran di kelas 3 yang masih tergolong sederhana. Salah satu contoh drill yang dilakukan oleh guru dengan media gambar kemudian siswa menebaknya dengan menggunakan bahasa Jepang adalah sebagai berikut:

Guru : (Guru hanya memperlihatkan gambar meja tanpa mengucapkan apapun)

Siswa: "Tsukue" (siswa menjawab secara bersamaan)

(Meja)

Srategi drill yang dilakukan oleh guru bertujuan untuk melatih huruf hiragana maupun katakana dan kosa kata-kosa kata yang telah diajarkan sebelumnya, serta untuk melihat sejauh mana pemahaman siswa mengenai materi yang telah diberikan. Drill yang diberikan oleh guru masih tergolong drill yang sederhana, yaitu berupa menebak, menulis atau membaca huruf dan kata, guru tidak meminta siswa menebak secara cepat namun memberikan waktu dan kesempatan untuk siswa menjawab dikarenakan tahap berpikir siswa pada kelas rendah masih tergolong abstrak.

Berdasarkan hasil observasi, strategi tanya jawab digunakan oleh guru dalam pembelajaran bahasa Jepang di setiap kelas yang diobservasi. Dalam strategi tanya jawab, interaksi dua arah dari guru kepada siswa ataupun siswa kepada guru sama-sama aktif. Hal ini sejalan dengan pendapat Djamarah (2013) yang menyatakan bahwa strategi tanya jawab merupakan strategi dalam bentuk pertanyaan yang harus dijawab oleh guru kepada siswa, dapat juga dijawab oleh siswa kepada guru. Strategi tanya jawab yang diterapkan guru menggunakan teknik information gap yang sederhana karena pembelajaran bahasa Jepang di kelas 3 masih tergolong sederhana dan belum sampai pada penggunaan kalimat yang kompleks.

Dapat terlihat bahwa strategi pembelajaran yang dilakukan di SD dengan strategi pembelajaran yang dilakukan di SMA tidak jauh berbeda walaupun jenis dan tahapan yang dicapai pada masing-masing strategi berbeda menyesuaikan dengan karakteristik perkembangan anak pada setiap tingkatan sekolah dan tingkat kesulitan bahan ajar yang diberikan. Tahapan pembelajaran pada SD hanya sampai pada pengetahuan (C1) dan pemahaman (C2) yang masih tergolong rendah, sedangkan tahapan pembelajaran di SMA sudah sampai evaluasi (C6) yang tergolong level tertinggi.

\section{Faktor yang Mendasari Penggunaan Strategi dalam Pembelajaran Bahasa Jepang}

1. Karakteristik Siswa

Karakteristik siswa merupakan hal utama yang mendasari guru menggunakan strategi atau teknik drill dan tanya jawab dalam kegiatan belajar mengajar di kelas. Karena jika diamati dari minat siswa dalam belajar, khususnya dalam belajar bahasa Jepang masih kurang. Hal ini disebabkan karena siswa masih tergolong siswa yang berada pada tingkatan kelas rendah yang mulai mencapai kematangan untuk belajar namun belum bisa untuk serius dan fokus belajar dalam waktu yang lama. Temuan ini sejalan dengan pendapat Diani (2014) yang menyatakan bahwa salah satu karakteristik peserta didik pada kelas rendah biasanya sudah mencapai kematangan, mampu mengontrol tubuh dan keseimbangannya. Drill dan tanya jawab yang dilakukan oleh guru selama proses belajar mengajar juga masih tergolong sederhana menyesuaikan materi yang diberikan berupa kosa kata dan kalimat pendek belum sampai pada kalimat percakapan yang kompleks. Temuan ini sejalan dengan pendapat Kawuryan (2011) yang menyatakan bahwa pada tahap usia sekolah dasar cara belajarnya berkembang secara bertahap dimulai dari hal yang sederhana sampai hal yang lebih kompleks.

Drill dan tanya jawab yang dilakukan oleh guru selama proses belajar mengajar juga masih tergolong sederhana menyesuaikan materi yang diberikan berupa kosa kata dan kalimat pendek belum sampai pada kalimat percakapan yang kompleks. Berdasarkan karakteristik siswa tersebut, guru menggunakan strategi drill untuk melatih pemahaman kosa kata dan kalimat siswa, strategi tanya jawab digunakan untuk melatih keterampilan siswa dalam berbicara serta membuat siswa menjadi lebih aktif.

2. Kondisi Siswa di Kelas

Kondisi siswa di kelas merupakan faktor kedua guru menggunakan strategi drill dan tanya jawab dalam kegiatan belajar mengajar di kelas. Proses pembelajaran akan berjalan 
dengan lancar jika seorang guru dapat mengontrol kondisi kelasnya. Jika guru tidak bisa menciptakan kondisi kelas yang sesuai dan kondusif untuk pembelajaran, maka pembelajaran tidak akan berjalan dengan lancar dan sesuai dengan rencana pelaksanaan pembelajaran (RPP) yang telah dibuat, serta tujuan pembelajaran tidak akan tercapai seperti yang diinginkan. Adanya interaksi yang baik yang terjadi antara guru dan siswa adalah keberhasilan suatu proses belajar mengajar. Strategi drill dan tanya jawab ini digunakan agar tidak hanya guru yang berperan aktif dalam proses pembelajaran, melainkan juga dengan siswa. Keterlibatan siswa dalam proses belajar mengajar akan menciptakan pembelajaran efektif serta kondisi kelas yang aktif dan menyenangkan.

\section{Kendala-kendala yang Dihadapi Guru dalam Pembelajaran Bahasa Jepang}

\section{Kendala Mengenai Media Pembelajaran}

Dalam pembelajaran bahasa asing diperlukan sebuah media pembelajaran yang merupakan salah satu hal yang penting untuk meningkatkan minat siswa dalam belajar, dan jika hanya menggunakan metode drill dan tanya jawab saja, pembelajaran semakin lama akan menjadi monoton dan membosankan. Fasilitas yang disediakan oleh pihak sekolah seperti LCD juga merupakan kendala bagi guru. Sekolah menyediakan fasilitas berupa LCD di setiap kelas, tetapi LCD tersebut tidak dapat berfungsi dengan baik dan terkadang listrik yang digunakan mati sehingga proses pembelajaran menjadi kurang maksimal. Selain itu, guru juga kurang inovatif dalam membuat media pembelajaran berupa media gambar. Berdasarkan hasil observasi guru lebih sering menjelaskan materi ataupun kosa kata tanpa menggunakan media sambil menyesuaikan dengan materi pelajarannya. Namun pada observasi keempat, guru terlihat menggunakan media gambar dalam melaksanakan drill, tetapi dalam pelaksanaannya media tersebut tidak lama digunakan dan drill tidak bisa dilakukan kepada seluruh siswa secara merata mengingat alokasi waktu pembelajaran yang tidak banyak. Guru mengatasi kendala dalam penggunaan media pembelajaran dengan berusaha sebisa mungkin menggunakan media baik itu media gambar ataupun yang lain.

2. Kendala Mengenai Alokasi Waktu

Alokasi waktu pembelajaran bahasa Jepang yang diberikan tidak cukup banyak. Hal tersebut menyebabkan guru tidak bisa menjelaskan materi sepenuhnya kepada siswa dan strategi pembelajaran yang digunakan juga tidak berjalan dengan optimal. Adanya interaksi yang baik yang terjadi antara guru dan siswa adalah keberhasilan suatu proses belajar mengajar. Strategi drill dan tanya jawab ini digunakan agar tidak hanya guru yang berperan aktif dalam proses pembelajaran, melainkan juga dengan siswa. Keterlibatan siswa dalam proses belajar mengajar akan menciptakan pembelajaran efektif serta kondisi kelas yang aktif dan menyenangkan.

Kemudian untuk kendala alokasi waktu guru berusaha untuk mengefisienkan waktu agar sesuai dengan rencana pelaksanaan pembelajaran (RPP) yang telah dibuat, lalu pada pembelajaran menulis huruf, pemahaman kosa kata dan kalimat sederhana, guru sering memberikan latihan yang dikerjakan di sekolah maupun menjadi pekerjaan rumah.

\section{Simpulan dan Saran}

Berdasarkan hasil penelitian dan pembahasan mengenai profil strategi pembelajaran bahasa Jepang di kelas 3 SD Saraswati 3 Denpasar, maka dapat disimpulkan sebagai berikut.

Sasaran pembelajaran bahasa Jepang di kelas 3 SD Saraswati 3 Denpasar terlihat lebih kompleks dari kelas sebelumnya. Sasaran pertama pada aspek menyimak yaitu siswa diharapkan mampu membedakan bunyi dan kata yang pengucapannya memiliki kemiripan. Sasaran kedua pada aspek berbicara yaitu siswa diharapkan mampu melafalkan bunyi, kata, dan mengucapkan salam. Sasaran ketiga pada aspek membaca yaitu siswa diharapkan mampu membaca tulisan dalam huruf katakana. Sasaran yang keempat pada aspek menulis yaitu siswa diharapkan mampu untuk menulis kata menggunakan huruf katakana

Strategi yang digunakan oleh guru bahasa Jepang di kelas 3 SD Saraswati 3 Denpasar adalah strategi drill dan Tanya jawab yang bertujuan agar siswa lebih aktif dan melatih kemampuan berbicara siswa sesuai dengan karakteristik siswa kelas rendah yang senang 
berbicara. Dalam pelaksanaannya guru memberikan waktu dan kesempatan pada siswa untuk menjawab dikarenakan cara berpikir siswa di kelas rendah yang masih abstrak. Guru lebih sering melakukan drill dan tanya jawab tanpa menggunakan media gambar, namun menggunakan media berupa benda-benda di dalam kelas menyesuaikan dengan materi. Strategi yang digunakan guru sudah sampai pada tahap pengetahuan (C1) dan pemahaman (C2) dalam ranah kognitif karena masih tergolong pembelajaran dasar dengan level rendah. Siswa dituntut menjawab berdasarkan hapalan pada tahap pengetahuan (C1) dan siswa dilatih untuk berani menjawab menggunakan pendapatnya sendiri sesuai pemahaman pada tahap C2. Jenis drill yang digunakan guru dalam pembelajaran yaitu repetition (pengulangan), sedangkan tanya jawab yang dilakukan guru menggunakan teknik information gap.

Faktor yang mendasari penggunaan strategi mengajar guru adalah karakteristik siswa yang minat belajarnya masih kurang karena masih tergolong kelas rendah yang belum fokus untuk belajar dalam waktu lama, senang berbicara, dan masih belajar dari hal yang sederhana ke hal yang lebih kompleks. Kondisi siswa di kelas juga menjadi faktor kedua guru menggunakan strategi drill dan tanya jawab dalam pembelajaran di kelas. Jika guru tidak dapat menciptakan kondisi kelas yang kondusif, maka pembelajaran tidak akan berjalan lancar dan sesuai dengan RPP yang telah dibuat.

Kendala-kendala yang dihadapi dalam pembelajaran bahasa Jepang di kelas 3 yaitu kendala mengenai media pembelajaran seperti LCD yang terdapat di kelas tidak berfungsi dengan baik, guru dalam proses belajar mengajar jarang menggunakan media gambar, serta kendala mengenai alokasi waktu pembelajaran yang diberikan tidak cukup banyak sehingga strategi pembelajaran yang digunakan guru tidak berjalan secara optimal.

Dengan adanya penelitan ini dalam proses pembelajaran, guru bahasa Jepang di SD Saraswati 3 Denpasar hendaknya mampu memvariasikan strategi pembelajaran dengan nyanyian atau permainan agar siswa lebih tertarik untuk belajar dan suasana kelas jadi lebih menyenangkan melihat karakter siswa yang masih ada pada tingkatan kelas rendah.

Guru bahasa Jepang di SD Saraswati 3 Denpasar seharusnya lebih memanfaatkan media pembelajaran seperti media gambar yang bersifat konkrit sehingga siswa SD khususnya pada tingkatan kelas rendah akan lebih tertarik belajar dan tujuan pembelajaran yang diinginkan dapat tercapai, dan perlunya peningkatan terhadap penelitian yang sejenis, sehingga dapat dijadikan acuan dalam memahami strategi pembelajaran yang digunakan guru pada mata pelajaran bahasa Jepang khususnya pada tingkat sekolah dasar.

\section{Daftar Pustaka}

Djamarah, Syaiful Bahri danAswan Zain. 2013. Strategi Belajar Mengajar. Jakarta: Rineka Cipta.

Hamalik, Oemar. 2011. Kurikulum dan Pembelajaran. Jakarta: Bumi Aksara. Perbukaan Departemen Pendidikan dan Kebudayaan dengan PT. Rineka Cipta.

Kawuryan. 2011. "Karakteristik Siswa SD Kelas Rendah dan Pembelajarannya". Tersedia pada

http://staffnew.uny.ac.id/upload/132313274/pengabdian/KARAKTERISTIK+DAN+CAR A+BELAJAR+SISWA+SD+KELAS+RENDAH.pdf. (diakses tanggal 8 november 2017).

Padmadewi M.A, Prof Ni Nyoman. 2012. Strategi Pembelajaran Bahasa. Singaraja.

Roestiyah. 2001. Strategi Belajar Mengajar. Jakarta: Rineka Cipta.

Sugiyono. 2007. Metode Penelitian Pendidikan (Pendekatan Kuantitatif, Kualitatif dan R \& D). Bandung: Alfabeta. 
JPBJ, Vol. 4 No. 2, Juli, 2018

Susanto, Ahmad. 2013. Teori Belajar dan Pembelajaran di Sekolah Dasar. Jakarta: Kencana Prenada Media Group.

Yogisswara, I Gede Putra. 2015. "Profil Strategi Mengajar Guru Bahasa Jepang di SMKN 1 Singaraja Tahun Ajaran 2014/2015". Tersedia pada https://ejournal.undiksha.ac.id/index.php//JJPBJ/article/view/6281 (diakses tanggal 23 Desember 2017). 